УДК 665.583.4: 547.587.11

DOI https://doi.org/10.11603/2312-0967.2019.1.9876

\title{
РОЗРОБКА СКЛАДУ ТА ТЕХНОЛОГІЇ ЗУБНОЇ ПАСТИ З МЕТИЛСАЛІЦИЛАТОМ
}

\author{
І. С. Гриновець, Т. А. Шостак, Ю. В. Яремишин, В. С. Гриновець \\ Львівський національний медичний університет імені Данила Галицького \\ i_hrynovets@ukr.net
}

\begin{abstract}
Мета роботи. Розробка складу та технології зубної пасти з метилсаліцилатом.
Матеріали і методи. Використано методи інформаційного пошуку, аналізу даних літератури та проведено експериментальні дослідження.

Результати й обговорення. Як активний фармацевтичний інгредієнт запропонованої зубної пасти використано метилсаліцилат, оскільки проявляє протимікробну, знеболювальну та протизапальну дії. Оптимальний склад зубної пасти визначали на підставі проведення власних експериментальних досліджень: натрійкарбоксиметилцелюлоза - гелеутворювач, кальцію карбонат - абразивний компонент, сахарин - коригент смаку, натрій гідрокарбонат пом'якшувач та регулятор лужно-кислотного балансу, гліцерин - вологоутримувач, ментол - коригент смаку, вода - розчинник.

Висновок. Розробка зубної пасти з метилсаліцилатом $€$ не лише розширенням асортиментної групи гігієнічних засобів - це удосконалений підхід до відновлення мікробіоцинозу, можливість більш ретельного очищення зубів від нальоту та освіження подиху, що є важливим при щоденному догляді за порожниною рота.
\end{abstract}

Ключові слова: зубний наліт; зубна паста; метилсаліцилат; порожнина рота.

Вступ. Частина працездатного населення (часто молоді люди), зважаючи на напружений денний графрік та надзвичайно динамічний спосіб життя, інколи дотримується хибної думки - що здорові зуби не обов'язково чистити кожного дня. Така категорія людей стає першими стоматологічними хворими. Фізіологічно через 2 год після прийому їжі на зубах утворюється м'який наліт, який бажано усунути відразу або у перші 6-8 год. Якщо цього не робити то, внаслідок фрізіологічних та біохімічних процесів у порожнині рота відбувається постійне виділення ротової рідини, до складу якої входять йони кальцію, які беруть участь у фрормуванні «м'якого» нальоту, що 3 часом перетворюється на «тверді» кальцифіковані відкладення (каміння на зубах). Наявність останнього впливає на зміну мікробного статусу, появи неприємного запаху з рота, розвитку карієсу та запальних захворювань ясен, внаслідок яких оголюється шийка зуба, збільшується рухомість зубів, виникає пародонтоз та втрата зубів. Отже, дотримання правил елементарної гігієни із застосуванням косметичних засобів має надзвичайно велике значення для здоров'я людини.

Матеріали і методи. У роботі використано методи інорормаційного пошуку, аналізу даних літератури та проведено експериментальні дослідження.

Результати й обговорення. Засоби та предмети догляду косметичні, за дослідженнями науковців, не лише здатні підвищити результативність гігієнічнопрофрілактичних заходів, але у складі медикаментоз- них курсів сприяти зменшенню рівня симптоматики захворювання та пришвидшувати час одужання стоматологічних хворих. Таке стає можливим за умови включення до загальної терапевтичної схеми ефективних високоякісних засобів для первинної гігієни перевагою яких $€$ комплексний широкий спектр дії та вміст у своєму складі відповідних активних компонентів [1].

Пародонтальний статус порожнини рота будь-якої людини є важливою складовою поняття «здоров'я» в цілому. На сьогодні запальні захворювання пародонта набувають дедалі ширшого розповсюдження і відповідно до статистичних даних, зі санації населення, окремих вікових груп доходять до показників у 90$100 \%$ [2].

Важливе місце у процесі профрілактики та гігієни цієї групи захворювань посідає догляд за порожниною рота та зубними рядами, який передбачає застосування ряду гігієнічних:

1) предметів із косметичного догляду у вигляді щітки між- та зубної, іригатора, йоржика міжзубного, зубочистки, гнучкої зубочистки, нитки фрлос, вощеної зубної стрічки, очищувача язика, капи, міжзубного стимулятора;

2) засобів із косметичного догляду у фрормі зубної пасти, зубного порошку, еліксиру, різного роду розчинів, наприклад, таких, як ополіскувач, а також жувальної гумки тощо [3].

Порожнина рота $€$ оптимізованою біочастиною макроорганізму, з відповідним середовищем розвитку

ISSN 2312-0967. Фармацевтичний часопис. 2019. № 1 
та співіснування різних видів мікроорганізмів, які за умов фрізіологічної норми - фрормують резидентну мікрофрлору. Таке співіснування можливе за рахунок низки сталих показників у порожнині рота, зокрема: різноманіття харчових ресурсів - у вигляді залишків їжі між зубами, постійно оновлюваний рівень вологості - у середньому 2 мл ротової рідини щохвилини з відповідним значенням рН, а також відповідний рівень температури створюють сприятливі умови для колонізації (різної за етіологією) та фрормуванню системи мікробіоцинозу [3].

Більшість науковців та лікарів практиків у своїх друкованих працях сьогодні вказує, що головною причиною розвитку ендогенних інфекцій $є$ втрата толерантності імунної системи організму до представників резистентної патогенної мікрофрлори. Оскільки захист макроорганізму здійснюється за допомогою так званих розпізнавальних рецепторів, які беруть участь у великій кількості імунних процесів і за рахунок чого відбувається специфічний вид контролю, не лише за сталістю клітинного складу органів і тканин людського організму, але і за числовими показниками патогенної та непатогенної мікрофрлори [4].

До загальної системи захисту людини від патогенної мікрофлори в області порожнини рота відносять такі чинники впливу: внутрішні - ферментативний склад ротової рідини, імуноглобуліновий та захист на клітинному рівні, мікробний антагонізм, фрізичний, що передбачає контроль за рівнем $\mathrm{pH}$ і температурними показниками тощо; зовнішні - у формі збалансованого харчування 3 перевагою грубої натуральної їжі (овочів, фрруктів) та активне і відповідне за тривалістю пережовування їжі; обмеження й відсутність згубних звичок (куріння, алкоголізму, наркоманії); відповідний гігієнічний догляд, що передбачає застосування відповідних предметів та засобів гігієни для порожнини рота.

3 метою щоденного гігієнічного догляду сьогодні найчастіше використовують зубні пасти, які за призначенням класифрікують як такі, що очищають, дезодорують і освіжають порожнину рота, зубні ряди та язик; знижують утворення зубного нальоту та каменю та ті, що містять фртористі сполуки.

До складу зубних паст переважно входять антисептичні засоби із широким спектром антибактеріальної дії; бактерицидні засоби - пригнічують або знищують певну групу бактерій; бактеріостатичні окремі комплекси орерментів, які розщеплюють м'який та твердий наліт, наприклад, змінюючи метаболізм бактеріальної клітини; неферментні диспергуючі чи модифікуючі чинники - змінюють структуру або метаболічну активність біофільму порожнини рота; антиадгезивні - перешкоджають прикріпленню всієї або деякої частини бактерій порожнини рота.

Найбільш поширеними на сьогодні бактерецидними сполуками, що забезпечують ефективність дії зубних паст та використовуються в умовах промис-
Фармацевтична технологія, біофармація, гомеопатія

Pharmaceutical technology, biopharmacy, homeopathy

лового виробництва, є хлоргексидин 0,2-0,4 \%, триклозан 0,2-0,3 \%, гексетидин, триклогард, лактат цинку, ефріроолійні протимікробні засоби та ін. [4].

Діючою речовиною у розробленій гігієнічній формі було обрано метилсаліцилат - органічний ефрір, який вперше було екстраговано та виділено з рослинних олійних видів Gaultheria procumbens у 1843 році, зараз виготовляється також синтетично. Також використовується у харчовій промисловості, входить до складу продуктів і напоїв як ароматизатор та у жувальних гумках і м'ясних заправках, у малих концентраціях з антисептичною метою [5].

У складі лікувальних лініментів із метою зменшення гострого суглобового та м'язового болю метилсаліцилат застосовується як протизапальний та зігрівальний засіб та як ароматична добавка у складі гігієнічних засобів із догляду за порожниною рота.

Таким чином, метилсаліцилат - діюча речовина, яка проявляє протимікробний ефект і застосовується зовнішньо як знеболювальний і протизапальний засіб. Застосовується 3 лікувальною метою у чистому вигляді і у комплексі з жирними оліями для втирання при суглобовому і м'язовому ревматизмі, артритах (запаленні суглоба), бруситах тощо.

3 метою виготовлення зубної пасти з метилсаліцилатом було опрацьовано компоненти складу пропису та розроблено універсальну рецептуру, до складу якої входять нижче наведені компоненти у співвідношенні:

$\begin{array}{ll}\text { Метилсаліцилат } & 0,5 \\ \text { аКМЦ } & 3,0 \\ \text { Полівініловий спирт (ПВС) } & 1,0 \\ \text { Натрію гідрокарбонат } & 5,0 \\ \text { Кальцію карбонат } & 15,0 \\ \text { Гліцерин } & 5,0 \\ \text { Сахарин } & 0,1 \\ \text { Ментол } & 0,2 \\ \text { Вода очищена до } & 100,0\end{array}$

Аналіз складу речовин, які фрормують основу зубної пасти, що додатково містить 0,5 \% метилсаліцилату.

Натрійкарбоксиметилцелюлоза (NaKMЦ) - гелеутворювач та піноутворювач напівсинтетичного походження; ПВС - речовина з групи ВМС синтетичного походження, проявляє протимікробні властивості; кальцію карбонат - абразивний компонент; натрій гідрокарбонат - проявляє абразивні та абсорбційні властивості і регулятор лужно-кислотного балансу, який додатково має здатність зменшувати чутливість зубів та ясен; гліцерин - солюбілізатор з емульгуючими властивостями, вологоутримувач, який загально у концентрації до 10 \% проявляє кератопластичну дію та прискорює процес регенерації епітеліальних тканин; сахарин - підсолоджувач та коригент смаку; ментол - коригент смаку з освіжаючими властивостями, а також проявляє легку місцеву анестезуючу дію; вода - розчинник. Технологічну схему виробництва зубної пасти з метилсаліцилатом наведено на рисунку 1.

ISSN 2312-0967. Pharmaceutical review. 2019. № 1 
Фармацевтична технологія, біофармація, гомеопатія

Pharmaceutical technology, biopharmacy, homeopathy

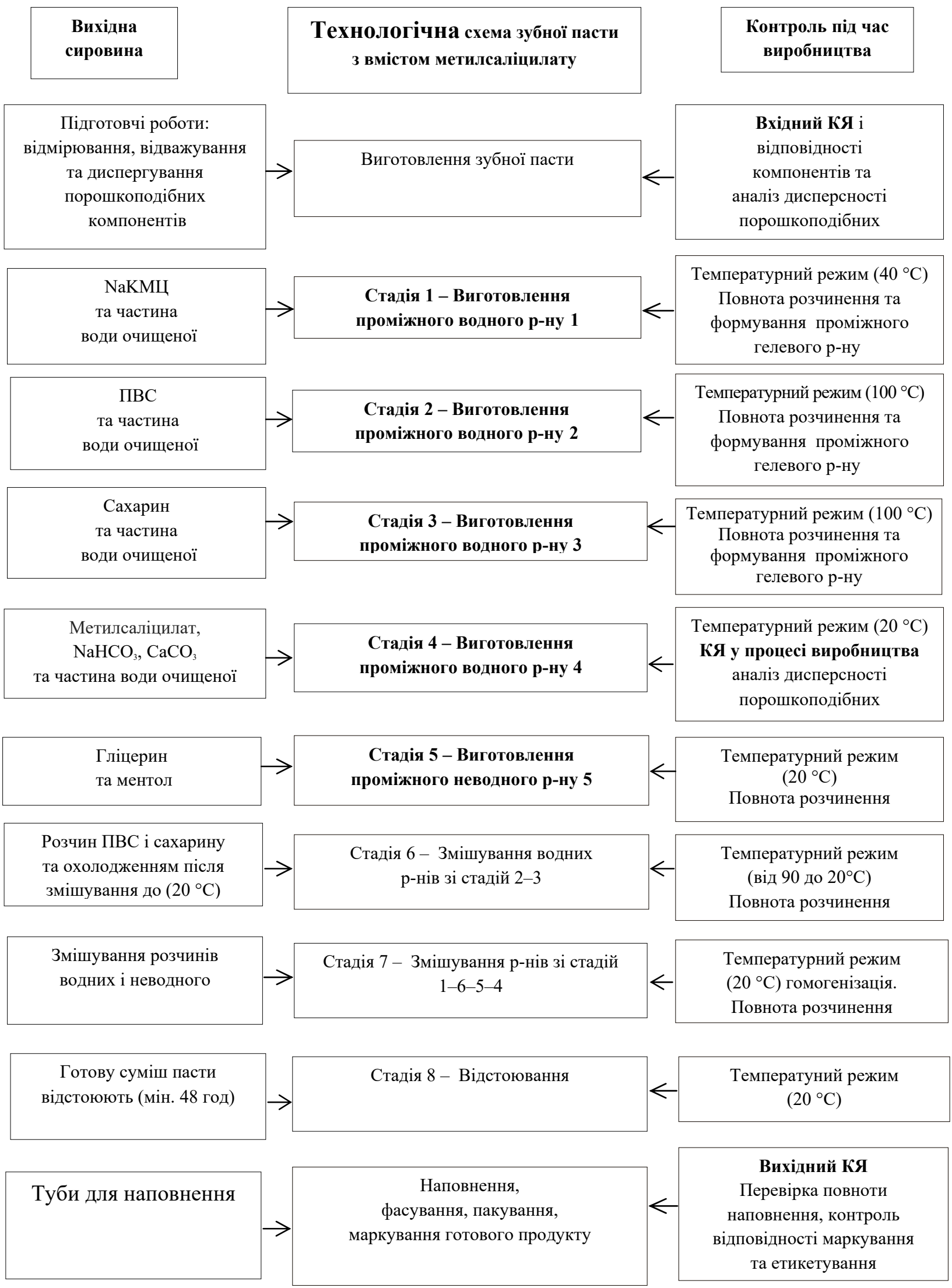

Рис. 1. Технологічна схема виробництва зубної пасти з метилсаліцилатом.

*КЯ - контроль якості

ISSN 2312-0967. Фармацевтичний часопис. 2019. № 1 
Розроблену зубну пасту з метилсаліцилатом досліджували, визначали: органолептичні, фрізичні, фрізико-хімічні та технологічні показники. Визначено такі параметри: отримана досліджувана пастоподібна маса візуально однорідна, в'язка, світло-коричневого кольору з характерним запахом м'яти, солодкувата на смак із характерним присмаком ментолу та метилсаліцилату. Діаметр окремо тестованих, після просіювання, частинок складав 0,16 мм, що відповідає вимогам до стандартизації відповідно до Державної Фармакопеї України (ДФУ) у розділі «Порошки» (ступені подрібнення). Критерії стандартизації зубної пасти 3 метилсаліцилатом наведено в таблиці 1.
Фармацевтична технологія, біофармація, гомеопатія Pharmaceutical technology, biopharmacy, homeopathy

- фрізико-хімічні та механічні - 3 метою підтвердження якісного складу встановлювали наявність метилсаліцилату та компонентів 3 абразивною дією (кальцію карбонату та натрію гідрокарбонату).

Стандартизацію зубної пасти з метилсаліцилатом здійснювали відповідно до вимог ГОСТ 7983-99 та ТУ У 00333919-002-95 «Пасти зубні (абразивні та гелеві)» та шляхом аналізу органолептичних і фрізикохімічних показників, які відповідно до методики стандартизації повинні відповідати відповідним вимогам і нормам [5].

Термін зберігання зубної пасти - 12 місяців від дня виготовлення.

Таблиця 1. Критерії стандартизації зубної пасти з метилсаліцилатом

\begin{tabular}{|l|c|c|}
\hline \multicolumn{1}{|c|}{ Найменування показника } & Одиниця вимірювання & Критерії якості зубної пасти \\
\hline Зовнішній вигляд & $*$ & Однорідна маса без сторонніх домішок \\
\hline Колір & $*$ & $\begin{array}{c}\text { Властивий кольору пасти даного } \\
\text { найменування }\end{array}$ \\
\hline Запах & $*$ & Властивий запаху даного найменування \\
\hline Смак & $*$ & $\begin{array}{c}\text { Властивий смаку пасти даного } \\
\text { найменування }\end{array}$ \\
\hline $\begin{array}{l}\text { Масова частка гліцерину, } \\
\text { не більше ніж }\end{array}$ & $\%$ & 33,0 \\
\hline Масова частка води очищеної & $\%$ & Залишкова \\
\hline Водневий показник,рН & Од. & $5,5-10,5$ \\
\hline
\end{tabular}

У процесі розробки були також проведені дослідження:

- мікробіологічні - згідно з вимогами ДФУ до показників мікробіологічної чистоти лікарських засобів для нашкірного застосування (Категорія 2) висуваються вимоги: загальна кількість життєздатних аеробних мікроорганізмів - не більше 100 (КУО/г) (аеробних бактерій і грибів сумарно); відсутність бактерій род. Enterobacteriaceae, S. Aureus, S. aeruginosa;
Висновок. Розробка зубної пасти з метилсаліцилатом $€$ не лише розширенням асортиментної групи гігієнічних засобів - це удосконалений підхід до відновлення мікробіоцинозу, можливість більш ретельного очищення зубів від нальоту та освіження подиху, що є важливим при щоденному догляді за порожнинною рота.

Конфлікт інтересів: відсутній.

Conflicts of interest: author has no conflict of interest to declare.

\section{РАЗРАБОТКА СОСТАВА И ТЕХНОЛОГИИ ЗУБНОЙ ПАСТЫ С МЕТИЛСАЛИЦИЛАТОМ}

\section{И. С. Гриновец, Т. А. Шостак, Ю. В. Яремышин, В. С. Гриновец}

Львовский национальный медицинский университет имени Данила Галицкого

i_hrynovets@ukr.net

Цель работы. Разработка состава и технологии зубной пасты с метилсалицилатом.

Материалы и методы. В работе использованы методы иноормационного поиска, анализ данных литературы и проведены экспериментальные исследования.

Результаты и обсуждение. В качестве действующего вещества предложенной зубной пасты использовано метилсалицилат, поскольку данный препарат проявляет противомикробное, обезболивающее и противовоспалительное действие. Оптимальный состав зубной пасты был определен на основании проведения собственных экспериментальных исследований: натрийкарбоксиметилцеллюлоза - гелеобразователь, кальция карбонат - абразивный компонент, сахарин - коригент вкуса, натрий гидрокарбонат - смягчитель и регулятор щелочнокислотного баланса, глицерин - влагоудерживающая составная, ментол - коригент вкуса, вода - растворитель.

Вывод. Разработка зубной пасты с метилсалицилатом является не только расширением ассортиментной группы гигиенических средств - это усовершенствованный подход к восстановлению микробиоциноза, возможность более

ISSN 2312-0967. Pharmaceutical review. 2019. № 1 
Фармацевтична технологія, біофармація, гомеопатія

Pharmaceutical technology, biopharmacy, homeopathy

тщательной очистки зубов от налета и освежения дыхания, является важным при ежедневном уходе за полостью рта.

Ключевые слова: зубной налет; зубная паста; метилсалицилат; полость рта.

\title{
DEVELOPMENT OF COMPOSITION AND TECHNOLOGY OF THE TOOTHPASTE WITH METHYLSALICYLATE
}

\author{
I. S. Hrynovets, T. A. Shostak, Yu. V. Yaremyshyn, V. S. Hrynovets \\ Danylo Halytskyi Lviv National Medical University \\ i_hrynovets@ukr.net
}

The aim of the work. Development of the composition and technology of a new toothpaste with methylsalicylate. Materials and Methods. Methods of information search, analysis of literature data and experimental research have been used.

Results and Discussion. As the active pharmaceutical ingredient of the proposed toothpaste, methylsalicylate is used because it exhibits antimicrobial, analgesic and anti-inflammatory effects. The optimal composition of the toothpaste has been determined on the basis of own experimental studies: sodium carboxymethyl cellulose - gel formulation, calcium carbonate - abrasive component, saccharin - flavor, sodium bicarbonate - softener and regulator of alkaline-acid balance, glycerol - moisture retainer, menthol - flavor, water - a solvent.

Conclusion. The development of a toothpaste with methyl salicylate is not only an extension of the range of hygiene products - it is an improved approach to restoring micro biocenosis, the ability to more thoroughly clean teeth from the plaque accumulation and breath freshening, which is important in the daily care of the oral cavity.

Key words: dental plaque; toothpaste; methyl salicylate; oral cavity.

\section{Список літератури}

1. Brandt F. S. Cosmeceuticals: current trends and market analysis / F. S. Brandt, A. Cazzaniga, M. Hann // Semin. Cutan. 2. Med. Surg. - 2011. - Vol. 30, No. 3. - P. 141-143. 2. Данилевський М. Ф. Заболевания пародонта / М. Ф. Данилевський, А. В. Борисенко. - Київ : «Здоров'я», 2000. - C. 87-108.

3. Reszko A. E. Cosmeceuticals: practical applications / A. E. Reszko, D. Berson, M. P. Lupo // Obstet. Gynecol. Clin. North. Am. - 2010. - Vol. 37, No. 4. - P. 547-569.

4. Дмитриева Л. А. Современные представления о роли микросрлоры в патогенезе заболеваний пародонта / Л. А. Дмитриева, А. Г. Крайнева // Пародонтология. 2004. - №1 (30). - C. 8-15.

5. Methyl salicylate /PubChem Compound Summary for CID 4133 [open chemistry database]. - Mode access https://pubchem.ncbi.nlm.nih.gov/compound/methyl_ salicylate\#section=Top

6. ГОСТ 7983-99 «Зубна паста» [Електронний ресурс]. - Режим доступу : http://docs.cntd.ru/document/1200006990.

\section{References}

1. Brandt FS, Cazzaniga A, Hann M. Cosmeceuticals: current trends and market analysis. Semin Cutan Med Surg. 2011;30(3): 141-3.

2. Danilevskiy MF, Borisenko AV. Periodontal disease. [Заболевания пародонта] Kyiv "Zdorovia"; 2000. Russian. 3. Reszko AE, Berson D, Lupo MP. Cosmeceuticals: practical applications. Obstet Gynecol Clin North Am. 2010;37(4) 547-69.

4. Dmitriyeva LA., Krayneva AG. [Modern ideas about the

role of microflora in the pathogenesis of periodontal disease]. Parodontologiya. 2004;1(30): 8-15.

5. Methyl salicylate / PubChem Compound Summary for CID 4133 [open chemistry database]. Available at: https://pubchem.ncbi.nlm.nih.gov/compound/methyl_ salicylate\#section=Top

6. GOST 7983-99 "Tooth paste". [ГОСТ 7983-99 "Зубна паста"] [Electronic source]. Available at: http://docs.cntd.ru/ document/1200006990. Ukrainian.

Надійшла до редакції / Received: 22.01.2019

Після доопрацювання / Revised: 04.02.2019

Прийнято до друку / Accepted: 14.02.2019

ISSN 2312-0967. Фармацевтичний часопис. 2019. № 1 
Фармацевтична технологія, біофармація, гомеопатія Pharmaceutical technology, biopharmacy, homeopathy

\section{Відомості про авторів:}

Гриновець І.С. - канд., фрармац. н., доц. каф. технології ліків і біофармації, Львівський національний медичний університет імені Данила Галицького, Львів, Україна. E-mail: i_hrynovets@ukr.net, ORCID 0000-0003-1727-3526

Шостак Т. А. - канд., фрармац. н., асист. кафр. технології ліків і біофармації, Львівський національний медичний університет імені Данила Галицького, Львів, Україна. E-mail: t_shostak8@ukr.net, ORCID 0000-0002-9679-0400

Яремишин Ю. В. - студент п'ятого року навчання фрармацевтичного фракультету, Львівський національний медичний університет імені Данила Галицького, Львів, Україна. E-mail: julya_139797@ukr.net , ORCID 0000-0002-0557-1713

Гриновець В. С. - канд., мед. н., доц. кафр. терапевтичної стоматології, Львівський національний медичний університет імені Данила Галицького, Львів, Україна. E-mail: hrynovets.v@gmail.com, ORCID 0000-0002-9651-4246

\section{Information about authors:}

Hrynovets I. S. - PhD (Pharmaceutical Sciences), Associate Professor, the Drug Technology and Biopharmaceutics Department, Danylo Halytsky Lviv National Medical University, Lviv, Ukraine. E-mail: i_hrynovets@ukr.net, ORCID 0000-0003-1727-3526

Shostak T. A. - PhD (Pharmaceutical Sciences), Assistant, the Drug Technology and Biopharmaceutics Department, Danylo Halytsky Lviv National Medical University, Lviv, Ukraine. E-mail: t_shostak8@ukr.net, ORCID 0000-0002-96790400

YaremyshynYu. V. - student of the fifth year of study, Pharmaceutical Faculty, Danylo Halytsky Lviv National Medical University, Lviv, Ukraine. E-mail: julya_139797@ukr.net, ORCID 0000-0002-0557-1713

Hrynovets V. S. - PhD (Medicine), Associate Professor, the Therapeutic Dentistry Department, Danylo Halytsky Lviv National Medical University, Lviv, Ukraine. E-mail: hrynovets.v@gmail.com, ORCID 0000-0002-9651-4246 